This is a self-archived - parallel published version of this article in the publication archive of the University of Vaasa. It might differ from the original.

\title{
Make-or-buy configurational approaches in product-service ecosystems and performance
}

Author(s): Bustinza, Oscar F.; Lafuente, Esteban; Rabetino, Rodrigo; Vaillant, Yancy; Vendrell-Herrero, Ferran

Title: Make-or-buy configurational approaches in product-service ecosystems and performance

Year: $\quad 2019$

Version: Accepted manuscript

Copyright C)2019 Elsevier. Creative Commons AttributionNonCommercial-NoDerivatives 4.o International (CC BY-NCND 4.o) license, https://creativecommons.org/licenses/by-ncnd/4.0/

Please cite the original version:

Bustinza, O. F., Lafuente, E., Rabetino, R., Vaillant, Y., \& Vendrell-Herrero, F., (2019). Make-or-buy configurational approaches in product-service ecosystems and performance. Journal of business research 104, 393-401. https://doi.org/10.1016/

j.jbusres.2019.01.035 


\title{
Make-or-Buy Configurational Approaches in Product-Service Ecosystems and Performance
}

\begin{abstract}
This research examines firm boundary configurations for manufacturers' product-service offerings. We argue that the building of a product-service ecosystem through collaboration with service providers in certain types of business services can increase performance as a result of the superior knowledge-based resources coming from specialized partners. By using fuzzy set qualitative analysis on a sample of 370 multinational manufacturing enterprises (MMNEs), the results reveal that effective servitization is heterogeneous across manufacturing industries and across business service offerings. The findings indicate that most industries achieve their highest performance through collaborations with value-added service providers in two out of three of the service continuum stages (Base and Intermediate services); while keeping the development of Advanced services in-house. The results help to contextualize the best practices for implementing service business models in MMNEs by detailing which service capabilities should be retained in-house and which should be outsourced to specialized partners in various industrial contexts.
\end{abstract}

Keywords: Servitization, Ecosystems, Make-or-buy, Knowledge-intensive business service firms, Product-service systems.

\section{Introduction}

Manufacturing businesses are increasingly introducing services to their traditional business models, a process typically described as servitization (Baines et al., 2017; Bustinza, Vendrell-Herrero, \& Baines, 2017a; Partanen, Kohtamäki, Parida, \& Wincent, 2017). Servitization has been typically described as a process that follows a service continuum. The model proposed by Baines and Lightfoot (2013), which builds on that developed previously by Oliva and Kallenberg (2003), is one of the most popular, and defines three stages of the service continuum, namely Base, Intermediate and Advanced services. Underlying this organizational transformation are potential increases in organizational outcomes, including competitive advantage and customer satisfaction (Bustinza, Bigdeli, Baines, \& Elliot, 2015; Vandermerwe \& Rada, 1988); as well as operational and economic performance, such as sales, profitability and growth (Bustinza 
et al., 2018; Kohtamäki, Partanen, Parida, \& Wincent, 2013; Suarez, Cusumano, \& Kahl, 2013). Like other organizational processes, servitized business models can also lead to negative outcomes (Benedettini, Neely, \& Swink, 2015; Suarez et al., 2013). Previous research has identified various factors that explain failed servitization, including limited capabilities (Sjödin, Parida, \& Kohtamäki, 2016), inefficient organizational configuration to develop product-service innovation (Bustinza et al., 2015), or poor make-or-buy decisions related to partner selection (Valtakoski, 2017).

The different stages of the service continuum - development of Base, Intermediate or Advanced service offerings_-yield different outcomes (Oliva \& Kallemberg, 2003; Parida, Rönnberg Sjödin, Wincent, \& Kotamäki, 2014; Tukker, 2004). Likewise, different organizational structures can be chosen to cater for each service offering and delivery (Bustinza et al., 2015; Turunen \& Toivonen, 2011). In particular, servitization involves strategic choices related to organizational configuration, partner selection and make-or-buy decisions (Martinez et al., 2017; Mathieu, 2001; Rabetino, Kohtamäki, \& Gebauer, 2017). Exceptions apart (e.g., Kowalkowski, Kindström, \& Witell, 2011; Paiola, Saccani, Perona, \& Gebauer, 2013), the empirical research on make-or-buy decisions in service provision is limited. As an illustrative example, the truck manufacturer MAN proposed a fleet management service to its industrial clients (i.e.., truck operators), which provided grounds for saving operating costs. Proprietary fleet management technologies were already available in the UK market, and MAN decided to collaborate with the leading fleet management company, Microlise. Given the success of the business model in the UK and the better understanding of the technology involved, MAN decided to internalize the fleet management service for its continental EU division (Bustinza et al., 2015).

While servitization strategies have been extensively studied in relation to product differentiation, the analysis of the outcomes resulting from different make-or-buy decisions along the service continuum has been sidelined in previous studies (Chirumalla, 2016). Servitization research therefore has yet to analyze how manufacturers choose make-or-buy configurations for each service offering categoryBase, Intermediate and Advanced. Following Kowalkowski et al. (2011), this article proposes that both the type of service offering and the market conditions determine the strategic choices governing the servitization decision, i.e., internally produced (make) or outsourced (buy) service provision. Accordingly, servitized manufacturers must balance 
the trade-off between existing internal and required external service capabilities through participation in business ecosystems (Kohtamäki \& Partanen, 2016; Kowalkowski et al., 2012; Nordin \& Ravald, 2016), where the boundary settings are selected in order to achieve effective collaborative business relationships (Bidgeli, Bustinza, VendrellHerrero, \& Baines, 2018). While each stage of the service continuum requires different service capabilities (Neely, 2008), different performance outcomes will be achieved along the service continuum depending on the suppliers' internal capabilities and the availability of capabilities that are outsourced to a network service provider (Kohtamäki et al., 2013; Ulaga \& Reinartz, 2011).

To address the above research gap, the purpose of this study is to analyze what service capabilities should be retained in-house and which should be outsourced to specialized partners so as to maximize organizational and business performance in the case of multinational manufacturing enterprises (MMNEs) operating in different industries. This study argues that the fit between the service offering and the make-orbuy decision may explain differences in performance among servitized manufacturers. The empirical analysis uses a novel approach to study the decisional outcome trajectories, i.e., fuzzy-set qualitative comparative analysis (fsQCA), on a sample of 370 servitized manufacturing firms from seven different industries. The sample firms operate worldwide; have their headquarters in America, Asia and Europe; and report annual revenues above one billion US dollars. The methodological approach selected (fsQCA) is an appropriate comparative method for determining the configurations that generate superior outcomes (Ragin \& Davey, 2014; Sjödin et al., 2016). This algorithmbased method has been proposed as an alternative to multiple regression analysis or structural equation modeling for testing predictive validity when studies face combinatory conditions with positive and negative influences on the outcome variable (Longest \& Vaisey, 2008; Woodside, 2013). Fuzzy set analysis is an appropriate statistical method for analyzing variables that operate in tandem (Base, Intermediate and Advanced services) at a specific level (in-house, outsourced).

The contributions of this study are twofold. First, the findings provide optimal boundary configurations per service category that maximize firm performance. Second, the proposed industry-level analysis contributes to the understanding of the industryspecific configurations underlying successful servitization strategies according to the optimal configuration of capabilities retained in-house and outsourced. Heterogeneity 
across sectors is studied and managerial implications for the different sectors are specified.

\section{Make-or-buy decisions and the product-service ecosystem configuration}

Empirical servitization research on how manufacturers use different make-or-buy arrangements to provide services is scarce (e.g., Kowalkowski et al., 2011; Paiola et al., 2013). Davies et al. (2007) suggest two ideal methods for organizing the sale and delivery of solutions: 1) the system integrator that coordinates the integration of components that are externally supplied by other firms and 2) the system seller that produces all product and service components in-house. The authors found no evidence to support either of these methods and suggested the rise of a complex hybrid form combining the advantages of both pure methods. In turn, Mathieu (2001) introduces a collaborative continuum (i.e.., internalization, partnering and outsourcing) and suggests that the "collaborative option" is not only a source of skills and resources, but may also help companies to minimize risk, focus on core activities, and moderate specific costs attached to implementing a service strategy.

As Mathieu (2001) and Kowalkowski et al. (2011) suggest, there are many potential configurations for organizing the provision and delivery of industrial services (i.e.., internal, external, or a range of hybrid options). While the collaborative option has different points of application (e.g., service development, and service performing backand front-office), there are many potential partners, such as distributors and dealers (e.g., Caterpillar and Volvo with their dealers), clients (e.g., GE Medical systems with its customers for training services), service providers (e.g., Philips with DHL and Laura Ashley with Federal Express for logistics services, or Volvo with Securitas for security services), and competitors (e.g., Matra with Renault for commercialization services). Although each option has specific financial, marketing, strategic and other benefits, the risks and costs increase with service specificity and organizational complexity (Mathieu, 2001).

Alternative configurations depend on many specific factors, and previous servitization research has found no best way to configure the provision of services. Accordingly, configurations not only seem to be highly contingent on the firm's offering and market-specific factors (e.g., degree of service orientation, availability of required resources, risk aversion, market channel characteristics, industry growth, size 
of the installed-base, and the rate of change in customer demand), but may also vary for the same firm across offerings and markets (Kowalkowski et al., 2012; Li, Huang, Cheng, Zheng \& Ji, 2014; Saccani, Johansson, \& Perona, 2007).

\subsection{Organizational configuration for industrial service provision}

The servitization literature typically defines the business service offering of manufacturing firms as a continuum that includes Base, Intermediate and Advanced services (Baines \& Lightfoot, 2013; Parida et al., 2014; Rabetino et al., 2017). For Base services, the outcome lies in the effective provision of goods (e.g., products and spare parts, and warranty contracts). Base services constitute a source of differentiation for manufacturing firms as they help to unveil customer needs (Giardelli, Saccani, \& Songini, 2007; Oliveira \& Azevedo, 2018; Porter \& Millar, 1985). In contrast, Intermediate services focus on product conditions (Oliva \& Kallenberg, 2003). Examples include maintenance contracts and agreements as well as repair services required to restore or maintain a product -e.g., monitoring of operator training or costplus contracts (Kim, Cohen, \& Netessine, 2007). Finally, Advanced services include output-based services and emphasize the provision of capability (e.g., risk and reward sharing contracts and customer support agreements) (Baines \& Lightfoot, 2013; Rabetino, Kohtamäki, Lehtonen, \& Kostama, 2015). In this latter category, R\&D services are a typical example, where services (e.g., feasibility studies or product performance problems) are conducted with the objective of identifying potential improvements in performance (Parida et al., 2014; Visnjic, Neely, \& Jovanovic, 2018).

To achieve the expected positive outcomes of servitization, manufacturers increasingly study the best organizational (functional unit) configuration for service provision (Araujo \& Spring, 2006). Firms seek to minimize latent trade-offs between units and functions (e.g., product and service units) and optimize potential synergies between functions that are conducive to superior competitive advantage (Porter \& Millar, 1985). Firms create new business functions - generally for intermediate or advanced services - to handle specific services, while internally developing the product unit (Bustinza et al., 2015). This strategic decision may imply additional costs and organizational malfunctions for those firms with decentralized production (Turunen \& Toivonen, 2011).

The 'separation vs. integration' debate (Oliva, Gebauer, \& Brann, 2012) is based on 
either theoretical consideration (Araujo \& Spring, 2006) or comparative case studies (Gebauer \& Friedli, 2005; Oliva \& Kallenberg, 2003; Turunen \& Toivonen, 2011). Moreover, the debate only considers different internal approaches to the service provision linked to units within the boundaries of the supplier organization (Kowalkowski et al., 2011). Recent studies have identified that value chain positioning affects make-or-buy decisions for advanced service provision (Baines et al., 2017; Bustinza et al., 2015; Visnjic et al., 2018). These findings have opened a debate that goes beyond functional unit configuration by suggesting the influential role of industryspecific characteristics. Manufacturing industries have different rates of change within their external environments due to technological or competitive factors-industry clock speed (Fine, 1998). Therefore, industry membership has been found to moderate the relationship between both the organizational and functional configuration of products and firm performance (see, e.g., Nadkarni, \& Narayanan, 2007; or Wiengarten, Pagell, \& Fynes, 2012).

This study goes further than the 'separation vs. integration' debate (Oliva et al., 2012) by analyzing how the configuration of service provision is heavily reliant on specific market characteristics. Existing servitization research has proposed some market-specific factors that affect the configuration of service provision. For instance, the internal option may work better in slow-growing and turbulent markets; in markets with a consolidated supplier base (Kowalkowski et al., 2011); in markets where customers demand complex product-service bundles; and where customer-relationships are the key to competitive advantage (Nordin, 2008). Overall, evidence seems to suggest that the selection of a better configuration is linked to the specific characteristics of each geographical market (Kowalkowski et al., 2011).

\subsection{Make-or-buy decisions inside ecosystems and the role of KIBS firms}

Technological factors are determinants of businesses' external market environments. Changing market conditions make it harder to respond quickly through in-house innovation (Veugelers \& Cassiman, 1999). Thus, technological pressures push firms to adopt make-or-buy decisions, and these pressures are higher among manufacturing firms that are less acquainted with product-service innovations (Brentani, 2001). Facing make-or-buy decisions, partnerships offer compelling advantages that are linked to the externalization of risks and company downsizing (Bigdeli et al., 2018). 
While partnerships in product innovation promote synergies and economies of scale through product standardization and cost minimization (Quinn \& Hilmer, 1994), partnerships in product-service innovation may enhance innovation outcomes by sharing knowledge (Bustinza, Gomes, Vendrell-Herrero, \& Baines, 2017b) and improving the understanding of customer needs (Vendrell-Herrero, Bustinza, Parry, \& Georgantzis, 2017). Consequently, strategic partnerships with KIBS firms constitute a valid type of alliance to encourage product-service innovation in manufacturing businesses (Kohtamäki \& Partanen, 2016; Lafuente, Vaillant, \& Vendrell-Herrero, 2017).

The decision to create a partnership with a KIBS may well be an internal strategic decision - e.g., to minimize risks by reallocating R\&D costs — or an imposed decisione.g., the appearance of disruptive innovation (Bigdeli et al., 2018). KIBS firms are crucial for facilitating service innovation, thereby helping to enhance the manufacturers' ecosystem (Czarnitzki \& Spielkamp, 2003). The term business ecosystem is used in the innovation management field to underline the interdependences, complementarities and coevolving capabilities among the members of an ecosystem (Adner \& Kapoor, 2010). The role of KIBS as bridges for innovation varies depending on the ecosystem in which they operate (Brax, Bask, Hsuan, \& Voss, 2017) and the services offered (Kamp \& Alcalde, 2014). We therefore propose that the outcome of a service business unit's configuration relies on a set of specific alliances with KIBS along the service continuum.

\subsection{A product-service configuration approach for high performance}

Although recent evidence suggests a positive effect of servitization on performance (Bustinza et al., 2017a; Kohtamäki et al., 2013; Visnjic \& Van Looy, 2013), analysis of the performance outcomes of servitization remains unclear. Some authors propose that the effect of product-service innovation on performance depends on contingency variables, including: a different organization of service units within manufacturing firms (Turunen \& Toivonen 2011); the firms' position in the value chain (Bustinza et al., 2015); or the collaborative partnerships established by the firms involved in the servitization process (Bustinza et al., 2017b). This study considers these variables and analyzes how product-service configurations help to achieve superior business and/or organizational performance depending on whether the service offering is developed 
(and delivered) in-house or outsourced. The analysis focuses on comparing the organizational and business performance implications of the various combinations of inhouse and outsourced service capabilities that can be identified along the service continuum.

The core capabilities view (Prahalad \& Hamel, 1990) theoretically underpins how a firm's configuration maximizes its key competencies. According to this theoretical framework, firms develop their strategic restructuring activities in order to better exploit their core capabilities and maximize their boundary configuration effects (Quinn \& Hilmer, 1994). In the present study, the different restructuring activities (Figure 1) involve managing partnership/outsourcing relationships with service providers for those service activities where the firm does not have core competences, while managing all remaining service activities in-house. In this regard, Huikkola, Kohtamäki and Rabetino (2016) show how servitizing companies create, leverage and release resources to support servitization. By doing so, they present a set of practices to deal with the 'separate vs. integrate' trade-offs (Oliva et al., 2012). Therefore, business service offerings are developed in-house or outsourced, and different configurations yield different performance levels. This proposition is in line with previous studies that have suggested that occasional alliances can improve a firm's offerings and, ultimately, its overall performance (Bigdeli et al., 2018; Larson, 1991; Mathieu, 2001; Sampson, 2007).

This theory and evidence lead us to propose that the configuration of the service offering affects the business and organizational outcomes of make-or-buy decisions along the service continuum. Indeed, the three types of service offering-Base, Intermediate and Advanced services — are subject to make-or-buy decisions and, on average, partnerships increase the positive effects of servitization on firm performance (Bustinza et al., 2017b) and innovation (Vendrell-Herrero, Gomes, Bustinza, \& Mellahi, 2018).

\section{Method}

\subsection{Data collection}

The data used in this study come from an international survey conducted by a USbased firm specialized in service management solutions in partnership with a global consultancy located in the UK. The international survey reached 370 service executives 
(including VPs for services and senior managers) of large MMNEs headquartered in three continents (North America, Europe, and Asia) with annual revenues of over one billion US dollars.

An advisory board validated the target population before implementation. The industry partner defined the population using internal business catalogs with information on more than 7,000 manufacturing firms. The objective was to generate a statistically representative sample of firms with a uniform distribution in terms of industry. By using a Gaussian distribution ${ }^{1}$ - fixing the confidence level at $95 \%$ - the procedure yielded a minimum target sample size of 365 respondents. Data were obtained using a recruited sample (Van Selm \& Jankowski, 2006), that is, respondents were given a password (by email) to control access to the online survey.

Companies were contacted on a weekly basis by phone and email in NovemberDecember 2013 until 370 multinational manufacturing enterprises had completed the online survey. All selected respondents are responsible for one or more cost or profit centers within their company's service businesses. More specifically, $45.9 \%$ of respondents are directors, $43.2 \%$ hold a corporate-level position, and $11.9 \%$ are executive vice-presidents.

\subsection{Model and sample description}

This study explores the configurations of the following business service offerings (Baines \& Lightfoot, 2013): Base services: (a) sales of service parts and/or (b) extended warranty contracts; Intermediate services: (c) cost-plus service contracts and/or (d) maintenance contracts; and Advanced services: (e) Value-added services, including, risk and revenue sharing as well as revenue through use. All these service offerings are included in the specific North American Industry Classification System (NAICS) codes (Gomes et al., 2018; Wong \& He, 2005) and are therefore relevant for the analysis of the servitization of manufacturers. Additionally, to measure whether a service has been undertaken in-house or outsourced, a categorical question associated with each business service offering was included in the survey.

\footnotetext{
${ }^{1} n=\frac{N * Z^{2} * p *(1-p)}{(N-1) * e^{2}+Z^{2} * p *(1-p)}$, where $n$ is the target sample size, $N$ is the population $(N=7000), Z=1.0+1.96$ (confidence level of $95 \%), e$ is the margin of error $(e=5 \%)$, and $p$ is a realistic estimate of the desired probability $(p=50)$.
} 
This study employs a multidimensional performance measure that includes recommended proximal and distal performance outcomes to offer a comprehensive description of the servitization-performance relationship (Sparrow \& Cooper, 2014). Proximal outcomes refer to common business performance metrics, such as profit margins, while distal outcome includes organizational performance indicators, such as competitive advantage (Yamin, Gunasekaran, \& Mavondo, 1999). Following previous studies (Bustinza et al., 2015, 2017b; Sparrow \& Cooper, 2014), 5-point Likert scales ( $1=$ Total disagreement, $5=$ Total agreement $)$ measure the main performance indicators . This approach is in line with Bustinza et al. (2017b) who measure performance using a two-dimensional construct: organizational performance (competitive advantage, higher customer satisfaction), and business performance (profit level, profit level change, increased profitability). The results of the principal components analysis in Table 1 report two components with Eigenvalues higher than 1, offering a rotated component matrix of two factors. Factor loadings are greater than $0.40(t>2.58$ and $p<0.01)$ as shown in Table 1. The result of the Kaiser-Meyer-Olkin index of sampling adequacy is higher than $0.80(\mathrm{KMO}=0.851)$, which corroborates that the sample is factorable. The result of Bartlett's test of sphericity $\left(\chi^{2}=245.033, p=0.000\right)$ confirms that the correlation between the analyzed variables does not contaminate the findings (Hair et al., 2012). The Total Variance Extracted is $61.34 \%$. A discriminant index is produced (all MMNEs are servitized), followed by a subset of criterion-referenced tests (for those companies at the extremes of the service continuum). Finally, following Acock (2013), internal consistency is tested using Cronbach's alpha $\left(\alpha_{1}=0.892\right)$ and Average Variance Extracted (0.626), while reliability is tested through Composite Reliability (0.845). As performance is a second-order construct with two factors -organizational and business performance- we validate the scale through Confirmatory Factor Analysis. Goodnessof-fit indicators of the performance construct are reported in Table 1.

--- Insert Figure 1 about here ---

--- Insert Table 1 about here ---

The sample contains MMNEs in seven evenly distributed industries: Aerospace and Defense (14.4\%), Automotive and Transportation (14.7\%), Commercial or Cargo Airlines (15.7\%), Electronics and High-Tech Equipment (14.7\%), Heavy and Industrial Equipment (14.0\%), Medical Devices and Equipment (12.6\%), and White Goods 
Manufacturing (13.7\%). The analysis in Figure 1 is performed for the full sample and each industry separately.

\subsection{Data analysis through fuzzy set qualitative comparative analysis}

The empirical analysis uses fuzzy set qualitative comparative analysis (fsQCA) to analyze asymmetric information (Longest \& Vaisey, 2008), that is, variables operating in tandem while measuring a combination of positive and negative effects on the outcome variable. Tandems are configured by the business service offerings (Base, Intermediate and Advanced services), the outcome variable being Business and Organizational performance. Fuzzy set qualitative comparative analysis has been used in recent studies dealing with optimal servitization configurations (Böhm, Eggert \& Thiesbrummel, 2017; Sjödin et al., 2016). Stata 15.1 software was used to analyze the data (Longest \& Vaisey, 2008). Through Boolean algebra, fuzzy set comparative analysis identifies causal variable conditions to achieve an outcome, whereby it was possible to test whether different combinations of causal variables lead to the same outcome (Lafuente, Vaillant, \& Leiva, 2018).

This technique requires the calibration of causal and outcome variables. In doing so, the software transforms the interval of causal or outcome variables into a fuzzy set score related to the degree of membership of the variable to this set. The values of the interval for causal or outcome variables are specified following three conditions: a) threshold for full membership condition (fuzzy score value $=0.95$ ), b) threshold for full non-membership condition (fuzzy score value $=0.05$ ), and $c$ ) threshold for cross-over point condition (fuzzy score value $=0.50$ ) that establishes present and absent conditions for the same variable (Ragin, 2008). Through this calibration, the set of variables is related to specific outcome levels (25th, 50th and 75 th percentile).

fsQCA differs from conventional statistical methods in various ways, and because of these differences, the method is appropriate for our analysis (Fiss, 2011). First, and as opposed to multiple regression/correlation analysis, fsQCA is asymmetric. Correlation analysis is symmetric by nature, that is, if a model relates some variables to high performance, the inverse of high performance will only change the sign of the coefficients (Fiss, 2011). The fuzzy set analysis is causally asymmetric: a set of causal conditions is specifically related to an outcome level, while the opposite conditions do not necessarily imply the absence of the outcome because it might be related to a 
different outcome level. Second, fsQCA is used to model the concept of conjunctural causation. This property allows combinations of various causal conditions to be linked to the outcome variable, rather than one predetermined condition. Third, and as opposed to linear regression models or structural equation models, fsQCA captures the idea of equifinality (Fiss, 2007). That is, fuzzy set models detect multiple causal paths and more than one combination of causal conditions may be found to be linked to the same outcome variable. Therefore, fsQCA reveals the specific combinations needed to achieve the highest specific outcome value.

In summary, fsQCA exploratively uncovers which causal conditions are necessary, and which are sufficient. Because of its comparative, non-deterministic approach, fsQCA is especially suitable for analyzing complex configurational patterns, equifinality, and multiple optimal conditions (Fiss, 2007). Also, rather than modeling predetermined linear relationships and computing the importance (impact) of specific and strictly independent effects across firms, fsQCA enables better identification of the strategic configurations that make sense in different types of businesses. fsQCA results therefore offer clearer implications than those generated from the marginal effects of regression analyses (Fiss, 2007, p. 1194).

\section{Results}

\subsection{Necessary analysis}

The analysis of necessary conditions is the first stage of fsQCA. This stage analyzes whether the consistency score of a combination of conditions -in our study whether Base, Intermediate or Advanced services are developed in-house or via a partnershipexceeds the threshold value of 0.9 (Sjödin et al., 2016). If this is the case, the combination of conditions is "necessary" or "almost always necessary." The results are shown in Table 2. Interestingly, none of the consistency scores exceeds the threshold, meaning that none of the conditions are necessary to achieve the highest performance. In other words, none of the service types in isolation is a necessary condition to achieve the highest level of organizational or business performance.

\subsection{Sufficiency analysis}


The "Truth Table Algorithm" is a more straightforward method in fsQCA analysis to test and show causal configurations that yield superior business or organizational performance (Ragin, 2008). The logic behind these configurations is the possibility of developing either in-house (Make - represented by a circle) or via a partnership (Buy - represented by O). As explained before, manufacturers' service offerings were categorized following Baines and Lightfoot's (2013) framework that establishes three kinds of service along the service continuum (Base, Intermediate and Advanced), while seven industries are analyzed in the current study. After carrying out the analysis of necessary conditions, the next step is to test the sufficient conditions to obtain causal configurations, establishing a threshold value of 0.75 to permit at least one case in the sample to be empirically relevant (Longest \& Vaisey, 2008; Pappas, Kourouthanassis, Giannakos, \& Chrissikopoulos, 2016). As shown in Table 3, all consistency values are above this threshold. Thus, servitization is a heterogeneous strategy, and optimal boundary configurations are sector-specific. From a managerial perspective, service transformation in manufacturing cannot be generalized, and it is critical to consider industrial and or market factors when analyzing product-service innovation.

Finally, unique coverage, by partitioning the raw coverage (Ragin, 2008), details the subset of firms that achieve the focal analyzed outcome. In other words, unique coverage shows the percentage of firms in the sample that achieve the highest business or organizational performance. Overall solution coverage scores assess the explanatory power of the solution over the outcome, like the $R$-squared in multivariate analysis (Forkmann, Henneberg, Witell, \& Kindström, 2017).

--- Insert Table 3 about here ---

Considering the entire sample, an analysis of the configurations that maximize business performance and organizational performance produces just one empirically relevant configuration: Base and Intermediate services are outsourced to KIBS while Advanced services are developed in-house. The same configuration-for both business and organizational performance — is found for the following industries: Heavy \& Industrial Equipment, Electronics \& High-Tech Equipment, and Automotive \& Transportation. The above configuration is relevant for achieving the highest Organizational performance, but is not pertinent for business performance in the case of 
the Aerospace \& Defense, and Commercial \& Cargo airlines industries. Interestingly, as opposed to the pattern described above, Medical Devices \& Equipment achieves the highest business and organizational performance by developing Base and Intermediate services in-house while collaborating with KIBS in the development of Advanced services. A discussion of these results can be found in the following section.

\section{Discussion of the results}

Our results have shown that considering the entire sample and most of the industry subsamples (Heavy \& Industrial Equipment, Electronics \& High-Tech Equipment, and Automotive \& Transportation), the configuration that maximizes both business and organizational performance is to outsource Base and Intermediate services to KIBS firms while undertaking Advanced services in-house. This is in line with the suggestions of some previous studies that found that advanced services are more difficult to outsource (Kowalkowski et al., 2011; Matthyssens \& Vandenbempt, 2008). Especially, Kowalkowski et al. (2011, p. 383) conclude that "advanced knowledge intensive services are likely to be provided in-house, whereas basic, personnel-intensive services may be externalized". Advanced services help manufacturers to develop distinctive capabilities that are delivered through product performance (Baines \& Lightfoot, 2013). Consistent with this view, the study's findings support the importance of keeping critical capabilities that influence manufacturers' competitive advantage in the organization (Huikkola et al., 2016; Kohtamäki et al., 2013; Ulaga \& Reinartz, 2011).

The highest Organizational performance for the Aerospace \& Defense and the Commercial \& Cargo Airlines industries is achieved through the same configuration. This result means that these industries (as in the case of the above-mentioned industries) understand the importance of Advanced services for achieving organizational performance, which is mostly related to market position and competitive advantage (Bustinza et al., 2015). Nevertheless, the highest business performance (as opposed to Organizational performance) in the Commercial \& Cargo Airlines industries is achieved through the opposite configuration; that is, developing Base and Intermediate services in-house and outsourcing Advanced services to KIBS firms. A plausible explanation for this relates to the heterogeneous consumer base as well as the high number of transactions present in these sectors. The higher the variety of consumers and the 
number of transactions, the higher the opportunities for KIBS firms to gain power in the business ecosystem by creating niche value-added services and providing knowledge support to manufacturers (Bigdeli et al., 2018; Vendrell-Herrero et al., 2017).

Finally, higher business and organizational performance for Medical Devices \& Equipment are achieved by developing Base and Intermediate services in-house and developing Advanced services through KIBS, which is in line with the findings of Antioco et al. (2008). This industry is not only characterized by its high customer variety but also by the important number of applications. This sector develops more than 14,000 different products as per the Global Medical Device Nomenclature (Ketikidis, Kontogeorgis, Stalidis, \& Kaggelides, 2010). The product range includes control devices, sensors, processors, storage, display, and transfer of information on anatomy and physiology. It is such a broad set of information and communication technologies that those Medical Devices \& Equipment manufacturers choose to develop Advanced services through specialized service providers. Therefore, this study adds contextual nuances to the decisive role of KIBS firms in the servitization-performance relationship. When customer orientation becomes more knowledge-intensive, KIBS become key agents for enhancing product-service innovation processes because of their higher capacity to collaborate and co-create with customers (Kohtamäki \& Partanen, 2016; Love, Roper, \& Bryson, 2011).

Hybrid configurations for the provision of industrial services seem to constitute a standard practice rather than an exception (Kowalkowski et al., 2011; Paiola et al., 2013). The results reveal three intersectoral differences, which can be described on the basis of the resulting optimal servitization approach and industry. For the first group of industries (Heavy \& Industrial Equipment, Electronics \& High-Tech Equipment, and Automotive \& Transportation), the results indicate an ideal configuration whereby Base and Intermediate services can be outsourced in order to avoid the fixed costs associated with the service structure. At the same time, the internalization of Advanced services would give the business full control of the most significant potential revenue streams in the after-market.

For the second group (White Goods Manufacturing and Medical Devices \& Equipment), the ideal solution indicates that companies should externalize all kinds of service. As the B2B activity of these companies is relatively small (in terms of the number of customers and transactions), rather than creating a costly internal structure, 
the efficient configuration includes the outsourcing of Advanced services to specialized providers that might deliver such services to the customers of several manufacturers. In contrast, the $\mathrm{B} 2 \mathrm{C}$ segment of these companies is typically characterized by a high number of transactions, price-sensitive customers and highly customized services. So, the recipe includes a shift towards externalization. In the search for organizational flexibility and lower risks and costs, technical services to the installed base and others such as logistical, financial and risk services can be outsourced to specialized companies.

In the last group of industries (Aerospace \& Defense and Commercial \& Cargo Airlines), the findings vary depending on the analyzed performance measure. When business performance is the outcome variable, the ideal configuration includes the internalization of Base and Intermediate services and the externalization of Advanced services. The results for organizational performance, however, suggest an optimal configuration based on the in-house development of Advanced services. Together, these findings suggest the existence of different short- and long-term benefits. In the shortterm, the benefits gained from the internalization of Base and Intermediate services include control of both access to the installed base and the provision of spare parts and repair services (the main service profit generators), which helps to minimize the possibility of suppliers and service partners moving into the after-market (becoming competitors). This configuration also includes the externalization of complex and costly Advanced services. In the long-run, and once the necessary service structure is in place, the internalization of Advanced services constitutes not only a potential stream of additional revenues, but also a relevant source of knowledge and information with implications for product/service development and, subsequently, for enhanced levels of customer satisfaction and loyalty.

\section{Implications and concluding remarks}

The present study deals with the effectiveness of servitization decisions (to internally produce [make] or outsource to [buy from] knowledge-intensive business service providers [KIBS]) across different manufacturing industries, and examines how the type of service offering conditions service provision-related decisions in different markets. This article offers a compelling view of the performance effects derived from the adoption of different servitization strategies. This result is consistent with previous 
studies that have pinpointed the strategic importance of collaborating with value-added service providers (Kohtamäki \& Partanen, 2016; Bigdeli et al., 2018), supporting the role of KIBS in enhancing performance for MMNEs (Bustinza et al., 2017a). By using a fuzzy set qualitative analysis on a sample of 370 servitized MMNEs manufacturers, the results indicate that organizations do not achieve the generally positive effects of servitization at the same intensity. More concretely, the critical finding of the study is that effective servitization is heterogeneous along the service continuum and across manufacturing industries.

The results of this paper have relevant implications for scholars and business managers. From an academic perspective, its key finding demonstrates that servitization is industry dependent. This supports previous work on the importance of developing and utilizing inter-organizational networks (Bastl, Johnson, Lightfoot, \& Evans, 2012) and successful service innovation strategies (Bustinza et al., 2015; Kohtamäki et al., 2013). Complementarities between the configurations of internal/external service business units explain the different outcomes of make-or-buy servitization decisions at the industry level.

The present study incorporates proximal outcomes (business performance indicators) and distal outcomes (organizational performance indicators - Sparrow \& Cooper, 2014), thus reinforcing the importance of both sets of indicators in generating a more comprehensive approach to performance in servitization research (Bustinza et al., 2017b). Notably, most of the configurations of make-or-buy decisions for achieving superior outcomes coincide-Base and Intermediate business service offerings through outsourced partnerships while developing Advanced services in-house. Exceptions are found in those industries where the variety of consumers, the high number of transactions, and the extensive product range mean that it is advisable to outsource Advanced services to specialized service providers. This result is a significant contribution as it introduces critical operational and market aspects for consideration when developing servitization (Rabetino et al., 2017); highlighting the importance of the continuous realignment of resources with the ecosystem where firms operate (Huikkola et al., 2016).

This article also helps to explain the crucial role of KIBS in servitization business ecosystems (Kohtamäki \& Partanen, 2016; Lafuente et al., 2017; Love et al., 2011). The results show that KIBS firms are present in some way in all configurations that lead to 
superior business or organizational performance. Additionally, in most industries, KIBS primarily perform Base and Intermediate tasks, while in some industries they are mostly responsible for providing Advanced services. Servitized MMNEs should achieve their critical capabilities by developing Advanced services in-house, except when the knowledge required is dispersed and outsourcing is therefore preferable. This result adds empirical evidence to the importance of understanding the technology involved in servitized manufacturers and their customers' needs (Bigdeli et al., 2018; Giardelli et al., 2007). KIBS develop critical competences in terms of customer knowledge and behavior and are enablers of new forms of service innovation, such as digital servitization (Vendrell-Herrero et al., 2017). This study therefore sheds light on the critical importance of KIBS for developing digital servitization, particularly in those industries where extensive market and customer knowledge is required. KIBS firms have specific competences that allow manufacturers to focus on their core competences (Prahalad \& Hamel, 1990; Lafuente et al., 2017), and create complementarities and synergies between KIBS and manufacturer resources to generate the coevolving capabilities of successful servitization (Sjödin et al., 2016) and, ultimately, enhance performance.

Recent studies have called for prescriptive recommendations to help manufacturers to master servitization strategies (Baines et al., 2017; Parida et al., 2014). This paper has implications for how manufacturing organizations can efficiently match solutions generated by product-service business models with the characteristics of both the industry and the business service offering to capitalize on the outcomes resulting from the implementation of different servitization strategies. Moreover, market and customer characteristics should also be taken into account, offering a broad vision of internal and external determinants of effective servitization. First, managers need to turn their attention to the characteristics both of the operational environment and of the desired service offering when considering the implementation of servitization strategies. Building on one of the most complete datasets covering senior managers' global strategies concerning make-or-buy decisions, the study provides alternative configurations that yield the same outcomes, thus allowing managers to contextualize servitization strategy-making in accordance with the available internal and external resources.

Second, by acknowledging that organizations pursue various objectives with 
different time horizons, the proposed analysis distinguishes business performancelinked to the achievement of economic results in the short-term-from organizational performance outcomes linked to the creation/development of competitive advantage and superior customer satisfaction levels in the long-run (Bustinza et al., 2015; Sparrow \& Cooper, 2014). To minimize the trade-offs between short and long-term orientation, this research demonstrates the importance of resource alignment for facilitating the development of the critical capabilities that arise from Advanced services (Baines \& Lightfoot, 2013).

Third, by identifying the necessary and sufficient conditions to maximize business and organizational performance, the study emphasizes the importance of strategic decisions concerning business ecosystems, inter-organizational networks and the organization of the business service offering. This outcome partially explains the differences in performance found in the literature (e.g., Benedettini et al., 2015; Suarez et al., 2013). Make-or-buy decisions allow firms to focus on their core capabilities (Prahalad \& Hamel, 1990). This study helps both to explain the relationship between product-service innovation and manufacturers' performance and to clarify the importance of business ecosystems for implementing service business models (Visnjic et al., 2018).

The limitations of the present study also represent avenues for future research. First, fuzzy set qualitative analysis is a novel technique that is gaining increased scholarly attention as an alternative to traditional tools, such as multiple regression or structural equation models (Lafuente et al., 2018). However, and despite similar results being reported in comparative studies using the same data (Woodside, 2013), the caseevidence research approach constitutes the main limitation of fuzzy set qualitative comparative analysis. Second, data availability does not permit the direct analysis of the relationship between the characteristics of KIBS, competition and the depth of servitization strategies among manufacturers. From a strategic perspective, specifically designed future research could address this point by evaluating how the adoption of servitization strategies (make-or-buy) is conditioned both by the characteristics of KIBS - e.g., number of firms, size, degree of specialization - and by information revealing that KIBS cooperate with multiple manufacturers operating in the same industry and market: direct competitors. Third, the sample contains a particular type of servitized product firm, namely large multinationals. We acknowledge that the results 
are contingent to the type of firm considered, and therefore an avenue for further research would be to test the optimal service configurations for product SMEs. Fourth, firms outsourcing their service units need to consider whether local or foreign partners are preferable (Vendrell-Herrero et al., 2018). In this vein, future studies should consider the importance of balancing geographic networks, cultural differences and customer proximity in order to accelerate servitization.

\section{References}

Acock, A. C. (2013). Discovering structural equation modeling using Stata. College Station, TX: Stata Press books.

Adner, R., \& Kapoor, R. (2010). Value creation in innovation ecosystems: How the structure of technological interdependence affects firm performance in new technology generations. Strategic Management Journal, 31(3), 306-333.

Antioco, M., Moenaert, R. K., Lingreen, A., \& Wetzels, M.G.M (2008). Organizational antecedents to and consequences of service business orientations in manufacturing companies. Journal of Academy of Marketing Science, 36(3), 337-358.

Araujo, L., \& Spring, M. (2006). Services, products, and the institutional structure of production. Industrial Marketing Management, 35(7), 797-805.

Baines, T., \& Lightfoot, H. (2013). Made to serve: How manufacturers can compete through servitization and product service systems. NY: John Wiley \& Sons.

Baines, T., Bigdeli, A., Bustinza, O. F., Guang Shi, V., Baldwin, J., \& Ridgway, K. (2017). Servitization: Revisiting the state-of-the-art and research priorities. International Journal of Operations \& Production Management, 37(2), 256-278.

Bastl, M., Johnson, M., Lightfoot, H., \& Evans, S. (2012). Buyer-supplier relationships in a servitized environment: An examination with Cannon and Perreault's framework. International Journal of Operations \& Production Management, 32(6), 650-675.

Benedettini, O., Neely, A., \& Swink, M. (2015). Why do servitized firms fail? A risk-based explanation. International Journal of Operations \& Production Management, 35(6), 946979.

Bigdeli, A., Bustinza, O. F., Vendrell-Herrero, F., \& Baines, T. (2018). Network positioning and risk perception in servitization: Evidence from the UK road transport industry. International Journal of Production Research, 56(6), 2169-2183.

Böhm, E., Eggert, A., \& Thiesbrummel, C. (2017). Service transition: A viable option for manufacturing companies with deteriorating financial performance? Industrial Marketing Management, 60, 101-111.

Brax, S. A., Bask, A., Hsuan, J., \& Voss, C. (2017). Service modularity and architecture: An overview and research agenda. International Journal of Operations \& Production Management, 37(6), 686-702.

Brentani, U. (2001). Innovative versus incremental new business services: Different keys for achieving success. Journal of Product Innovation Management, 18(3), 169-187.

Bustinza, O. F., Bigdeli, A. Z., Baines, T., \& Elliot, C. (2015). Servitization and competitive advantage: The importance of organizational structure and value chain position. ResearchTechnology Management, 58(5), 53-60. 
Bustinza, O.F., Vendrell-Herrero, F., \& Baines, T. (2017a). Service implementation in manufacturing: An organizational transformation perspective. International Journal of Production Economics, 192, 1-8.

Bustinza, O. F., Gomes, E., Vendrell-Herrero, F., \& Baines, T. (2017b). Product-service innovation and performance: The role of collaborative partnerships and R\&D intensity. $R \& D$ Management, In Press.

Bustinza, O.F., Vendrell-Herrero, F., Gomes, E., Lafuente, E., Opazo, M., Rabetino, R., \& Vaillant, Y. (2018). Product-service innovation and performance: Unveiling the complexities', International Journal of Business Environment. 10(2), 95-111.

Chirumalla, K. (2016). Organizing lessons learned practice for product-service innovation. Journal of Business Research, 69(11), 4986-4991.

Czarnitzki, D., \& Spielkamp, A. (2003). Business services in Germany: Bridges for innovation. The Service Industries Journal, 23(2), 1-30.

Davies, A., Brady, T., \& Hobday, M. (2007). Organizing for solutions: Systems seller vs. systems integrator. Industrial Marketing Management, 36(2), 183-193.

Fine, C. H. (1998). Clockspeed: Winning industry control in the age of temporary advantage. Reading, MA: Perseus.

Fiss, P. C. (2007). A set-theoretic approach to organizational configurations. Academy of Management Review, 32(4), 1180-1198.

Fiss, P. C. (2011). Building better causal theories: A fuzzy set approach to typologies in organization research. Academy of Management Journal, 54(2), 393-420.

Forkmann, S., Henneberg, S. C., Witell, L., \& Kindström, D. (2017). Driver Configurations for Successful Service Infusion. Journal of Service Research, 20(3), 275-291.

Gaiardelli, P., Saccani, N., \& Songini, L. (2007). Performance measurement of the after-sales service network: Evidence from the automotive industry. Computers in Industry, 58(7), 698-708.

Gebauer, H., \& Friedli, T. (2005). Behavioral implications of the transition process from products to services. Journal of Business \& Industrial Marketing, 20(2), 70-78.

Gomes, E., Bustinza, O. F.; Tarba, S.; Khan, Z.; Ahammad, M. (2018). Antecedents and implications of territorial servitization. Regional Studies, In Press.

Hair, J.F., Anderson, R. E., Tatham, R.L., \& Black, W. (2001). Multivariate data analysis. London: Prentice- Hall Pearson Education.

Huikkola, T., Kohtamäki, M., \& Rabetino, R. (2016). Resource realignment in servitization. Research-Technology Management, 59(4), 30-39

Kamp, B., \& Alcalde, H. (2014). Servitization in the Basque economy. Strategic Change, 23(56), 359-374.

Ketikidis, P. H., Kontogeorgis, A., Stalidis, G., \& Kaggelides, K. (2010). Applying eprocurement system in the healthcare: The EPOS paradigm. International Journal of Systems Science, 41(3), 281-299.

Kim, S. H., Cohen, M. A., \& Netessine, S. (2007). Performance contracting in after-sales service supply chains. Management Science, 53(12), 1843-1858.

Kohtamäki, M., Partanen, J., Parida, V., \& Wincent, J. (2013). Non-linear relationship between industrial service offering and sales growth: The moderating role of network capabilities. Industrial Marketing Management, 42(8), 1374-1385.

Kohtamäki, M., \& Partanen, J. (2016). Co-creating value from knowledge-intensive business services in manufacturing firms: The moderating role of relationship learning in suppliercustomer interactions. Journal of Business Research, 69(7), 2498-2506.

Kowalkowski, C., Kindström, D., \& Witell, L. (2011). Internalisation or externalisation? Managing Service Quality: An International Journal, 21(4), 373-391. 
Kowalkowski, C., Kindström, D., Alejandro, T. B., Brege, S., \& Biggemann, S. (2012). Service infusion as agile incrementalism in action. Journal of Business Research, 65(6), 765-772.

Lafuente, E., Vaillant, Y., \& Vendrell-Herrero, F. (2017). Territorial servitization: Exploring the virtuous circle connecting knowledge-intensive services and new manufacturing businesses. International Journal of Production Economics, 192, 19-28.

Lafuente, E., Vaillant, Y., \& Leiva, J. C. (2018). Sustainable and traditional product innovation without scale and experience, but only for KIBS!. Sustainability, 10(4), 1169.

Larson, A. (1991). Partner networks: Leveraging external ties to improve entrepreneurial performance. Journal of Business Venturing, 6(3), 173-188.

Li, G., Huang, F. F., Cheng, T. C. E., Zheng, Q., \& Ji, P. (2014). Make-or-buy service capacity decision in a supply chain providing after-sales service. European Journal of Operation Research, 239, 377-388.

Longest, K. C., \& Vaisey, S. (2008). Fuzzy: A program for performing qualitative comparative analyses (QCA) in Stata. Stata Journal, 8(1), 79-104.

Love, J. H., Roper, S., \& Bryson, J. R. (2011). Openness, knowledge, innovation and growth in UK business services. Research Policy, 40(10), 1438-1452.

Martinez, V., Neely, A., Velu, C., Leinster-Evans, S., \& Bisessar, D. (2017). Exploring the journey to services. International Journal of Production Economics, 192, 66-80.

Mathieu, V. (2001). Service strategies within the manufacturing sector: Benefits, costs and partnership. International Journal of Service Industry Management, 12(5), 451-475.

Matthyssens, P. \& Vandenbempt, K. 82008). Moving from basic offerings to value-added solutions: Strategies, barriers, and alignment. Industrial Marketing Management, 37(3), $316-328$.

Nadkarni, S., \& Narayanan, V. K. (2007). Strategic schemas, strategic flexibility, and firm performance: The moderating role of industry clockspeed. Strategic Management Journal, 28(3), 243-270.

Neely, A. (2008). Exploring the financial consequences of the servitization of manufacturing. Operations Management Research, 1(2), 103-118.

Nordin, F. (2008). Linkages between service sourcing decisions and competitive advantage: A review, propositions, and illustrating cases. International Journal of Production Economics, 114(1), 40-55.

Nordin, F. \& Ravald, A. (2016). Managing relationship gaps: a practitioner perspective. Journal of Business Research, 69(7), 2490-2497.

Oliva, R., Gebauer, H., \& Brann, J.M. (2012) Separate or integrate? Assessing the impact of separation between product and service business on service performance in product manufacturing firms. Journal of Business-to-Business Marketing, 19(4), 309-334.

Oliva, R., \& Kallenberg, R. (2003). Managing the transition from products to services. International Journal of Service Industry Management, 14(2), 160-172.

Oliveira, J., \& Azevedo, A. (2018). Antecedents and consequences of servitization in the office printing industry. International Journal of Business Environment, 10(1), 52-74.

Paiola, M., Saccani, N., Perona, M., \& Gebauer, H. (2013). Moving from products to solutions: Strategic approaches for developing capabilities. European Management Journal, 31(4), 390-409.

Pappas, I. O., Kourouthanassis, P. E., Giannakos, M. N., \& Chrissikopoulos, V. (2016). Explaining online shopping behavior with fsQCA: The role of cognitive and affective perceptions. Journal of Business Research, 69(2), 794-803.

Parida, V., Rönnberg Sjödin, D., Wincent, J., \& Kohtamäki, M. (2014). Mastering the transition to product-service provision: Insights into business models, learning activities, and capabilities. Research-Technology Management, 57(3), 44-52. 
Partanen, J., Kohtamäki, M., Parida, V., \& Wincent, J. (2017). Developing and validating a multi-dimensional scale for operationalizing industrial service offering. Journal of Business \& Industrial Marketing, 32(2), 295-309.

Porter, M., \& Millar, V. (1985). How information gives you competitive advantage. Harvard Business Review, 58, 149-160.

Prahalad, C. K. \& Hamel, G. (1990). The core competence of the corporation. Harvard Business Review, May/June, 79-91.

Quinn, J. B., \& Hilmer, F. G. (1994). Strategic outsourcing. Sloan Management Review, 35(4), 43.

Rabetino, R., Kohtamäki, M., \& Gebauer, H. (2017). Strategy map of servitization. International Journal of Production Economics, 192, 144-156.

Rabetino, R., Kohtamäki, M., Lehtonen, H., \& Kostama, H. (2015). Developing the concept of life-cycle service offering. Industrial Marketing Management, 49, 53-66.

Ragin, C. C. (2008). Redesigning social inquiry: Fuzzy sets and beyond (Vol. 240). Chicago: University of Chicago Press.

Ragin, C. C., \& Davey, S. (2014). Fuzzy-set/qualitative comparative analysis 2.5. Department of Sociology, University of California.

Saccani, N., Johansson, P., \& Perona, M. (2007). Configuring the after-sales service supply chain: A multiple case study. International Journal of Production Economics, 110(1-2), $52-69$.

Sampson, R. C. (2007). R\&D alliances and firm performance: The impact of technological diversity and alliance organization on innovation. Academy of Management Journal, 50(2), 364-386.

Sjödin, D.R., Parida, V., \& Kohtamäki M. (2016). Capability configurations for advanced service offerings in manufacturing firms: Using fuzzy set qualitative comparative analysis. Journal of Business Research, 69(11), 5330-5335.

Sparrow, P., \& Cooper, C. (2014). Organizational effectiveness, people and performance: New challenges, new research agendas. Journal of Organizational Effectiveness: People and Performance, 1, 2-13.

Suarez, F. F., Cusumano, M. A., \& Kahl, S. J. (2013). Services and the business models of product firms: An empirical analysis of the software industry. Management Science, 59(2), $420-435$.

Tukker, A. (2004). Eight types of product-service system: eight ways to sustainability? Experiences from SusProNet. Business Strategy and the Environment, 13(4), 246-260.

Turunen, T. T., \& Toivonen, M. (2011). Organizing customer-oriented service business in manufacturing. Operations Management Research, 4(1-2), 74-84.

Ulaga, W., \& Reinartz, W. J. (2011). Hybrid offerings: How manufacturing firms combine goods and services successfully. Journal of Marketing, 75(6), 5-23.

Valtakoski, A. (2017). Explaining servitization failure and deservitization: A knowledge-based perspective. Industrial Marketing Management, 60, 138-150.

Vandermerwe, S., \& Rada, J. (1988). Servitization of business: Adding value by adding services. European Management Journal, 6(4), 314-324.

Van Selm, M., \& Jankowski, N. W. (2006). Conducting online surveys. Quality \& Quantity, $40(3), 435-456$.

Vendrell-Herrero, F., Bustinza, O. F., Parry, G., \& Georgantzis, N. (2017). Servitization, digitization and supply chain interdependency. Industrial Marketing Management, 60, 6981 . 
Vendrell-Herrero, F., Gomes, E., Bustinza, O. F., \& Mellahi, K. (2018). Uncovering the role of cross-border strategic alliances and expertise decision centralization in enhancing productservice innovation in MMNEs. International Business Review. 27(4), 814-825.

Veugelers, R., \& Cassiman, B. (1999). Make and buy in innovation strategies: Evidence from Belgian manufacturing firms. Research Policy, 28, 1, 63-80.

Visnjic, I., \& Van Looy, B. (2013). Servitization: Disentangling the impact of service business model innovation on manufacturing firm performance. Journal of Operations Management, 31(4), 169-180.

Visnjic, I., Neely, A., \& Jovanovic, M. (2018). The path to outcome delivery: Interplay of service market strategy and open business models. Technovation. In Press.

Wiengarten, F., Pagell, M., \& Fynes, B. (2012). Supply chain environmental investments in dynamic industries: Comparing investment and performance differences with static industries. International Journal of Production Economics, 135(2), 541-551.

Wong, P. K., \& He, Z. L. (2005). A comparative study of innovation behaviour in Singapore's KIBS and manufacturing firms. The Service Industries Journal, 25(1), 23-42.

Woodside, A. G. (2013). Moving beyond multiple regression analysis to algorithms: Calling for adoption of a paradigm shift from symmetric to asymmetric thinking in data analysis and crafting theory. Journal of Business Research, 66(4), 463-472.

Yamin, S., Gunasekaran, A., \& Mavondo, F. T. (1999). Relationship between generic strategies, competitive advantage and organizational performance: An empirical analysis.

Technovation, 19(8), 507-518. 


\section{List of Figures}

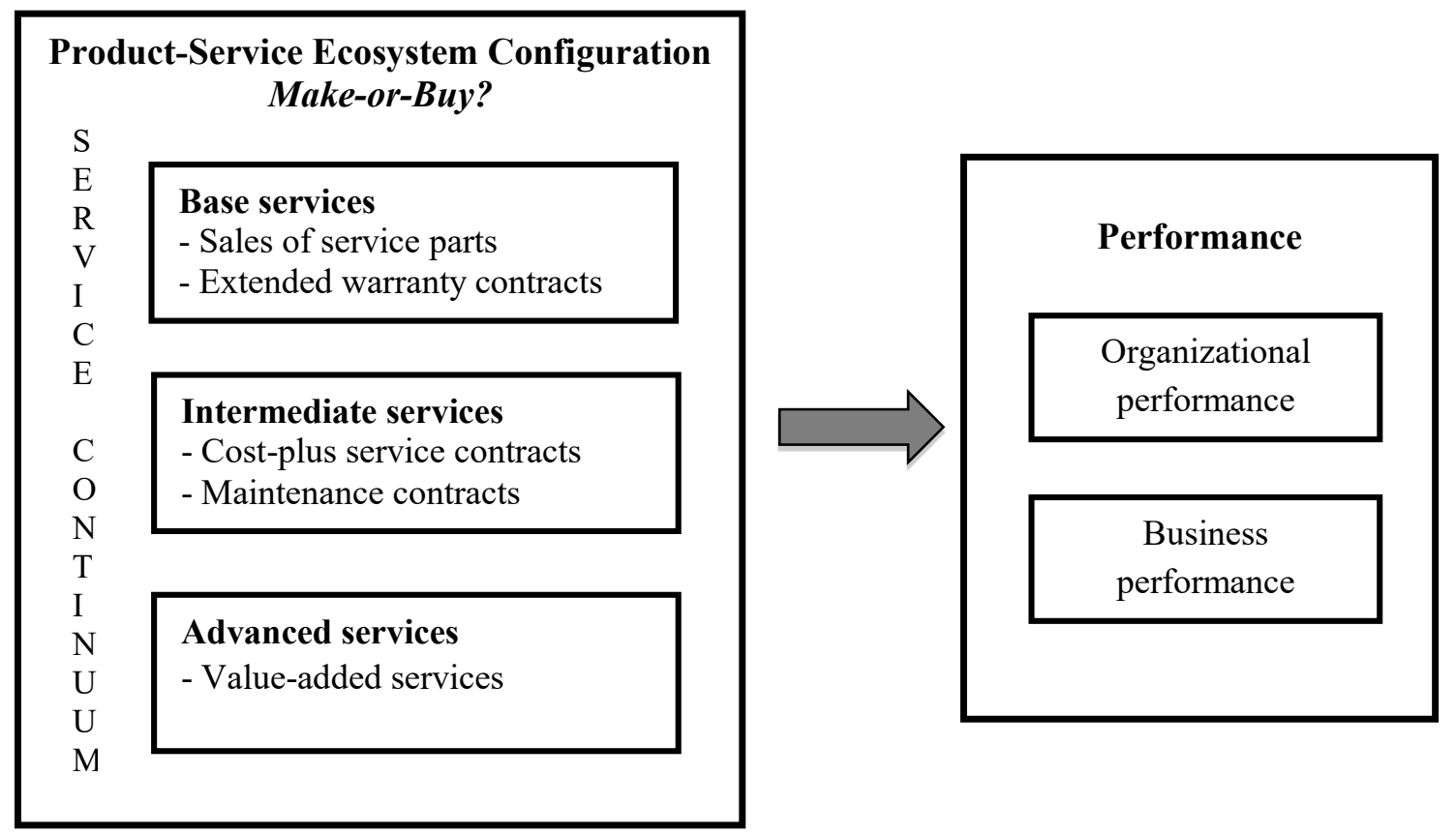

Figure 1. A configurational product-service approach to superior organizational and business performance 


\section{List of Tables}

Table 1. Factor loadings and reliability analysis

\begin{tabular}{l|l|l|l|l|l|l}
\hline Items & Factor 1 & Factor 2 & $\begin{array}{l}\text { Factor loading } \\
\text { (t-values) }\end{array}$ & $\mathrm{R}^{2}$ & $\begin{array}{l}\text { Composite } \\
\text { reliability }\end{array}$ & $\begin{array}{l}\text { Variance } \\
\text { extracted }\end{array}$ \\
\hline ORGPER1 & 0.591 & & $0.713(38.239)$ & 0.508 & & 0.845 \\
ORGPER2 & 0.603 & & $0.732(41.618)$ & 0.536 & & 0.626 \\
BUSPER1 & & 0.662 & $0.818(56.413)$ & 0.670 & &. \\
BUSPER2 & & 0.716 & $0.835(57.337)$ & 0.697 & & \\
BUSPER3 & & 0.648 & $0.797(48.314)$ & 0.635 & & \\
\hline
\end{tabular}

Chi-square likelihood: $\chi^{2}(4)=15.176(p=0.004) ; R M S E A=0.045 ; S R M R=0.031$ $C F I=0.983 ; R_{\text {Explor }}^{2}=0.341 ; \rho_{\text {reliability }}=0.845$

All of the factor loadings are significant for a level of $\mathrm{p}<0.01$

Table 2. Analysis of necessary conditions

\begin{tabular}{l|l|l|l|l}
\hline Outcome variable & \multicolumn{2}{|l|}{ Business performance } & \multicolumn{2}{l}{ Organizational performance } \\
\hline Conditions tested & Consistency & Coverage & Consistency & Coverage \\
Base services & 0.678 & 0.619 & 0.671 & 0.625 \\
Intermediate services & 0.631 & 0.581 & 0.612 & 0.575 \\
Advanced services & 0.497 & 0.483 & 0.494 & 0.476 \\
\hline
\end{tabular}


Table 3. Servitization configurations for achieving superior performance

\begin{tabular}{|c|c|c|c|c|c|c|}
\hline & \multicolumn{6}{|c|}{ Outcome variables } \\
\hline & \multicolumn{3}{|c|}{ Business performance } & \multicolumn{3}{|c|}{ Organizational performance } \\
\hline $\begin{array}{l}\text { Industry / type of } \\
\text { service }\end{array}$ & Base & Intermediate & Advanced & Base & Intermediate & Advanced \\
\hline \multirow[t]{2}{*}{ All Industries } & O & O & - & ○ & O & $\bullet$ \\
\hline & \multicolumn{3}{|c|}{$\begin{array}{c}\mathrm{C}=0.772 / \mathrm{R}=0.508 / \mathrm{UC}=0.508 / \\
\mathrm{OSCy}=0.772 / \mathrm{OSCe}=0.508\end{array}$} & \multicolumn{3}{|c|}{$\begin{array}{c}\mathrm{C}=0.775 / \mathrm{R}=0.372 / \mathrm{UC}=0.372 / \\
\mathrm{OSCy}=0.775 / \mathrm{OSCe}=0.372\end{array}$} \\
\hline \multirow{2}{*}{$\begin{array}{l}\text { Industry: } \\
\text { Heavy \& Industrial } \\
\text { Equipment }\end{array}$} & O & O & $\bullet$ & O & O & $\bullet$ \\
\hline & \multicolumn{3}{|c|}{$\begin{array}{c}\mathrm{C}=0.833 / \mathrm{R}=0.413 / \mathrm{UC}=0.413 / \\
\mathrm{OSCy}=0.833 / \mathrm{OSCe}=0.413\end{array}$} & \multicolumn{3}{|c|}{$\begin{array}{c}\mathrm{C}=0.771 / \mathrm{R}=0.383 / \mathrm{UC}=0.383 / \\
\mathrm{OSCy}=0.771 / \mathrm{OSCe}=0.383\end{array}$} \\
\hline \multirow{2}{*}{$\begin{array}{l}\text { Industry: } \\
\text { Electronics \& High } \\
\text { Tech Equipment }\end{array}$} & O & O & $\bullet$ & O & O & $\bullet$ \\
\hline & \multicolumn{3}{|c|}{$\begin{array}{c}\mathrm{C}=0.775 / \mathrm{R}=0.332 / \mathrm{UC}=0.072 / \\
\mathrm{OSCy}=0.785 / \mathrm{OSCe}=0.436\end{array}$} & \multicolumn{3}{|c|}{$\begin{array}{c}\mathrm{C}=0.869 / \mathrm{R}=0.383 / \mathrm{UC}=0.383 / \\
\mathrm{OSCy}=0.869 / \mathrm{OSCe}=0.383\end{array}$} \\
\hline \multirow{2}{*}{$\begin{array}{l}\text { Industry: } \\
\text { Automotive \& } \\
\text { Transportation }\end{array}$} & $\bigcirc$ & - & $\bullet$ & O & O & $\bullet$ \\
\hline & \multicolumn{3}{|c|}{$\begin{array}{c}\mathrm{C}=0.762 / \mathrm{R}=0.411 / \mathrm{UC}=0.411 / \\
\mathrm{OSCy}=0.762 / \mathrm{OSCe}=0.411\end{array}$} & \multicolumn{3}{|c|}{$\begin{array}{c}\mathrm{C}=0.792 / \mathrm{R}=0.371 / \mathrm{UC}=0.371 / \\
\mathrm{OSCy}=0.792 / \mathrm{OSCe}=0.371\end{array}$} \\
\hline \multirow{2}{*}{$\begin{array}{l}\text { Industry: } \\
\text { Aerospace \& } \\
\text { Defense }\end{array}$} & $\bullet$ & - & 0 & $\mathrm{O}$ & 0 & $\bullet$ \\
\hline & \multicolumn{3}{|c|}{$\begin{array}{c}\mathrm{C}=0.774 / \mathrm{R}=0.214 / \mathrm{UC}=0.043 / \\
\mathrm{OSCy}=0.755 / \mathrm{OSCe}=0.274\end{array}$} & \multicolumn{3}{|c|}{$\begin{array}{c}\mathrm{C}=0.800 / \mathrm{R}=0.456 / \mathrm{UC}=0.456 / \\
\mathrm{OSCy}=0.800 / \mathrm{OSCe}=0.456\end{array}$} \\
\hline \multirow{2}{*}{$\begin{array}{l}\text { Industry: } \\
\text { Commercial \& } \\
\text { Cargo airlines }\end{array}$} & ○ & 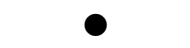 & O & O & O & 0 \\
\hline & \multicolumn{3}{|c|}{$\begin{array}{c}\mathrm{C}=0.800 / \mathrm{R}=0.532 / \mathrm{UC}=0.532 / \\
\mathrm{OSCy}=0.800 / \mathrm{OSCe}=0.532\end{array}$} & \multicolumn{3}{|c|}{$\begin{array}{c}\mathrm{C}=0.830 / \mathrm{R}=0.150 / \mathrm{UC}=0.051 / \\
\mathrm{OSCy}=0.858 / \mathrm{OSCe}=0.226\end{array}$} \\
\hline \multirow{2}{*}{$\begin{array}{l}\text { Industry: } \\
\text { White Goods } \\
\text { Manufacturing }\end{array}$} & O & $\bullet$ & O & O & O & O \\
\hline & \multicolumn{3}{|c|}{$\begin{array}{c}\mathrm{C}=0.764 / \mathrm{R}=0.318 / \mathrm{UC}=0.318 / \\
\mathrm{OSCy}=0.764 / \mathrm{OSCe}=0.318\end{array}$} & \multicolumn{3}{|c|}{$\begin{array}{c}\mathrm{C}=0.875 / \mathrm{R}=0.167 / \mathrm{UC}=0.167 / \\
\mathrm{OSCy}=0.875 / \mathrm{OSCe}=0.167\end{array}$} \\
\hline \multirow{2}{*}{$\begin{array}{l}\text { Industry: } \\
\text { Medical Devices \& } \\
\text { Equipment }\end{array}$} & - & - & O & $\bullet$ & - & O \\
\hline & \multicolumn{3}{|c|}{$\begin{array}{c}\mathrm{C}=0.877 / \mathrm{R}=0.253 / \mathrm{UC}=0.072 / \\
\mathrm{OSCy}=0.847 / \mathrm{OSCe}=0.346\end{array}$} & \multicolumn{3}{|c|}{$\begin{array}{c}\mathrm{C}=0.858 / \mathrm{R}=0.279 / \mathrm{UC}=0.279 / \\
\mathrm{OSCy}=0.858 / \mathrm{OSCe}=0.279\end{array}$} \\
\hline
\end{tabular}

Black circles "O" indicate that business units are managed within the company, unfilled circles " $O$ " indicate that they are managed through partnerships/outsourcing, and a hyphen "_" indicates indifference. "C" means Consistency; "R" Raw coverage; "UC” Unique Coverage; "OSCy": Overall Solution Consistency; "OSCe": Overall Solution Coverage 